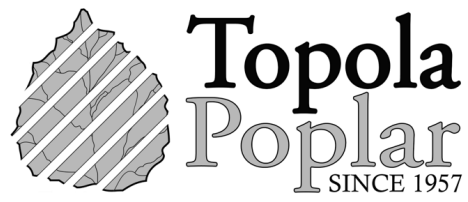

Original scientific paper

\title{
Fungal Microflora Biodiversity of Healthy and Diseased Adansonia digitata and Sclerocarya birrea Trees in Kenya
}

\author{
Sheillah Cherotich 1,*, Japhet Muthamia 1, Jane Njuguna ${ }^{2}$, Alice Muchugi ${ }^{3}$, Daniel Otaye ${ }^{1}$, \\ Ignazio Graziosi ${ }^{3}$, Zakayo Kinyanjui ${ }^{3}$ \\ 1 Department of Biological Sciences, Egerton University, P.O Box 536-20115, Njoro, Kenya \\ 2 Department of Plant Pathology, Kenya Forestry Research Institute, P.O Box 20412-00200, \\ Nairobi, Kenya \\ 3 Genetic Resource Unit, World Agroforestry Centre, P.O Box 30677-00100, Nairobi, Kenya \\ * Corresponding author: Sheillah Cherotich; E-mail: cherotich.sheillah@yahoo.com
}

Received: 13 Jan 2020; Revised: 10 Feb 2020; Accepted: 27 Feb 2020

\begin{abstract}
A study was conducted in Eastern Kenya to assess incidence and severity of Adansonia digitata and Sclerocarya birrea diseases under seasonal variations, and to assess associated fungal genera and their distribution. Asymptomatic and symptomatic tissues were sampled from 175 randomly selected trees. Isolations were done from leaves, twigs and bark following laboratory standard procedures. Samples were plated on Malt Extract Agar (MEA) and incubated at $25^{\circ} \mathrm{C}$ for 7 days. Fungal colonies were evaluated, and pure cultures were obtained using a single hypha. Fungal pathogens were identified based on morphological characteristics of cultures and spores. Statistical analysis were done using GENSTAT version 18. Fungal morphotypes isolated included: Pestalotia (39.0\%), Botryosphaeria (41.0\%), Fusarium (12.0\%), Alternaria (7.9\%) and Cladosporium $(0.1 \%)$. There were no stastically significant differences $(\mathrm{p}<0.01)$ in number of isolated fungi among different plant samples and sampling locations. This is the first detailed study on fungal diversity associated with diseased and healthy A. digitata and S. birrea trees in Kenya and it clearly indicates the need for detailed studies of fungal species isolated to develop mitigation strategies.
\end{abstract}

Keywords: Adansonia digitata, Botryosphaeria, Fusarium, fungal microflora, Pestalotia, Sclerocarya birrea.

\section{Introduction}

Indigenous fruit trees in Africa contribute to nutritional security and income for the dryland communities (Gebauer et al. 2016). Across Sub-Saharan Africa, wild fruits are used for wide range of purposes (Jamnadass et al. 2011), they improve nutrition, boost food security, foster rural development and support sustainable landscape management (Chivandi et al. 2015). Sclerocarya birrea (A. Rich.) Hochst. (marula), is a multipurpose tree which is a source of nutrients, livelihood and food security (Mkwezalamba et al. 2015) for developing countries. The plant parts can be used for food, medicine and beverages (Gebauer et al. 2014), with key nutrient of Vitamin 
A. Adansonia digitata L. (baobab) occurs in dry areas of Sub-Saharan Africa, the plant parts are used for food and medicine. The fruit pulp is of high nutritional value, especially regarding calcium and vitamin C (Stadlmayr et al. 2013). Therefore, baobab and marula are highly prioritized tree species for domestication and utilization in Africa (Kehlenbeck et al. 2013).

Diseased $A$. digitata and S. birrea trees, with various symptoms: canker, dieback and leafspots/blight were observed on farms. Branch and stem cankers which varied in size were characterized by visible lesion with exudation of gum which was initially creamish turning yellow and dark brown with time and vascular discoloration; dieback with dying of peripheral branches and leaf spots were characterized by development of necrotic lesions. Many woody plants host a high richness of fungi with most being latent, but they shift to pathogenic phase due to unfavourable conditions for the host (Pavlic-Zupanc et al. 2017). Previous studies have linked Botryosphaeria spp. to be the predominant causative agent of canker and dieback of trees worldwide (Burgess et al. 2019). Several Botryosphaeria spp. were isolated from S. birrea in South Africa (Mehl et al. 2017), and few also from baobab in South Africa, Namibia, Botswana, Mozambique and Madagascar (Cruywagen et al. 2017). Pestalotia spp. have also been associated with dieback of various tree species various dieback of trees; tree decline of Mangifera indica in India (Kumad et al. 2017), twig blight of blueberry (Vaccinium corymbosum) in China (Zhao et al. 2014), twig dieback and canker on blueberry (Vaccinium corymbosum) in Spain (Borrero et al. 2018) but no isolates have been obtained from baobab and marula. Fusarium species have also been linked to canker and dieback of Tea (Camellia sinensis) in Sri Lanka (Sinnah et al. 2017), and canker disease of Dalbergia tonkinensis in Vietnam (Nhung et al. 2018). However, knowledge of fungal communities associated with diseased baobab and marula trees in Kenya is unknown.

The objectives of this study were to: (1) assess incidence and severity of major diseases of A. digitata and S. birrea in Eastern Kenya, (2) to determine distribution and diversity of associated fungal microflora with focus on potential pathogens.

\section{Material and methods}

\subsection{Study sites}

Study sites were in Tiva, Ikanga (Kitui County) and Mukange (Makueni County) in Eastern Kenya which are the dry areas where baobab and marula are native trees. Kitui County is hot and dry, located between latitudes $0^{\circ} 10^{\prime} \mathrm{S}-03^{\circ} 0^{\prime} \mathrm{S}$ and $37^{\circ} 50^{\prime} \mathrm{E}-39^{\circ} 0^{\prime} \mathrm{E}$ and is located between $400 \mathrm{~m}$ and $1800 \mathrm{~m}$ above sea level, with annual temperatures ranging from $14^{\circ} \mathrm{C}$ to $34^{\circ} \mathrm{C}$ (Jaetzold et al. 2012), experiencing hot months between September - October and January March. Rainfall on the other side ranges between $250 \mathrm{~mm}$ and $1050 \mathrm{~mm}$ per annum. Makueni Country stretches from latitude $01^{\circ} 35^{\prime} \mathrm{S}-03^{\circ} 01^{\prime} \mathrm{S}$ from north to south and longitudes $37^{\circ} 10^{\prime} \mathrm{E}$ $38^{\circ} 30^{\prime}$ E from East to West. Majority of Makueni county lies within agroecological zone 5 (AEZ 5 ) in the semi-arid region of Eastern Kenya which is hot and dry receiving mean annual rainfall of $231 \mathrm{~mm}$ and $361 \mathrm{~mm}$ during long and short rains respectively. The mean maximum temperature of the area is $25^{\circ} \mathrm{C}$ and the mean minimum temperature is $13^{\circ} \mathrm{C}$ (Jaetzold et al. 2010).

\subsection{Disease incidence and severity assessment}

The survey was conducted in two seasons: 1. January to February, and 2. April to May 2018. Disease incidence was estimated by the total number of trees with canker and dieback symptoms expressed as the percentage of the total number of trees counted per farm. Disease severity was recorded as the percentage of the tree showing canker and dieback disease symptoms rated on six grade severity scale as described by Njuguna et al. (2011). 


$$
\text { Percentage of disease incidence }(\mathrm{PDI})=\frac{\text { Total number of infected trees }}{\text { Total number of trees assessed }} \times 100
$$

Percentage of disease severity $(P D S)=\frac{(1 \times a)+(2 \times b)+(3 \times c) \ldots+(6 \times f)}{N(\text { number of trees assessed } \times \text { maximum scale })} \times 100$

where: 1, 2, 3, 4, 5 and 6 are severity categories, and a, b, c, d, e and $\mathrm{f}$ are the numbers of trees examined in each severity category.

\subsection{Sampling and fungal isolation}

A total of 150 symptomatic and 25 asymptomatic trees were sampled. From each selected tree, three samples were collected showing any of the disease symptoms; leaf spots and blight, dieback and stem canker with resin flow. In addition, three samples were also taken from leaves, branches and stems of healthy trees. Samples were cut from the trees and placed in bags, labelled and stored in a cooled box. Fungal isolations were performed within 24 hours from sample collection. Pieces were cut from edges of a diseased tissue and from healthy samples; surface sterilized by immersing them in $70 \%$ Ethanol for $1 \mathrm{~min}$, then immersed in 33\% hydrogen peroxide for one minute and rinsed three times in sterile distilled water and blotted dry with sterile filter papers. Pieces were then plated on petri dishes containing $2 \%$ malt extract agar (MEA) amended with streptomycin sulfate (100 mg/l) (Merck, Germany) and incubated at $25^{\circ} \mathrm{C}$ for a week under alternating light and dark cycles of 12 hours. Emerging hyphae were aseptically isolated under a dissecting microscope, transferred onto $2 \% \mathrm{MEA}$, and cultures were assigned a unique number.

\subsection{Isolate grouping and identification using colony morphology}

Two weeks after sub-culturing, fungal colonies were grouped using colony morphological characteristics like colony color and mycelia texture using a dissecting microscope (NIKON SM2B, Japan). Spores were mounted on microscope slides in $85 \%$ lactic acid and examined microscopically ( $\times 1000$ magnification) to group and further identify the obtained fungi. The number of times each morphological group (frequency) occurred from a sample was recorded. Pure single hyphae cultures were transferred to potato dextrose agar (PDA) and stored at $4^{\circ} \mathrm{C}$ for further studies. Colony colors (upper surface and reverse) were determined with the charts of Rayner (1970).

\subsection{Data analysis}

Statistical analysis of data was performed using GenStat version 18. One-way ANOVA was used to test significance in occurrence of pathogens on different parts of the two tree species and on different sites and means separated using Tukey Test.

\section{Results}

\subsection{Survey of disease incidence and severity on A. digitata and S. birrea trees under seasonal} variation in Eastern Kenya

Canker and dieback disease were widespread in the two Agro-ecological zones (Makueni and Kitui), and in total 30\% of the 150 trees assessed showed symptoms of canker and dieback. Disease incidence varied between 20 and $47 \%$ during wet season and between 30 and $69 \%$ during 
dry season. Disease severity varied between 6 and 12.5\% during wet season and between 7 and $25.2 \%$ during dry season as shown in Table 1 . Sclerocarya birrea trees showed the highest incidence and severity of the disease compared to $A$. digitata trees across the sites.

Table 1. Incidence and severity of canker and dieback symptoms on A. digitata and S. birrea trees in Eastern Kenya.

\begin{tabular}{llcccc}
\hline \multirow{2}{*}{ Location } & \multirow{2}{*}{ Tree species } & \multicolumn{2}{c}{$\begin{array}{c}\text { Incidence } \\
\mathbf{( \% )}\end{array}$} & \multicolumn{2}{c}{$\begin{array}{c}\text { Severity } \\
\text { (\%) }\end{array}$} \\
\cline { 3 - 6 } & & wet season & dry season & wet season & dry season \\
\hline \multirow{2}{*}{ Tiva } & Adansonia digitata & 20 & 30 & 6.0 & 7.0 \\
& Sclerocarya birrea & 26 & 70 & 6.7 & 21.3 \\
\hline \multirow{2}{*}{ Ikanga } & \multirow{2}{*}{ Adansonia digitata } & 42 & 54 & 12.3 & 21.8 \\
\hline \multirow{2}{*}{ Kibwezi } & Adansonia digitata & 40 & 57 & 10.8 & 23.0 \\
& Sclerocarya birrea & 47 & 69 & 12.5 & 25.2 \\
\hline
\end{tabular}

${ }^{1}$ The incidence was determined per trees inspected per farm

2 The severity was estimated according to damage index

\subsection{Fungal morphotypes}

The morphotypes identified corresponded to five genera, including; Botryosphaeria, Pestalotia, Fusarium, Alternaria and Cladosporium mainly. Isolates of Botryosphaeria produced aerial mycelium that was initially whitish turning greyish white, dark greenish grey or blackish grey within two weeks and it also produced light brown ovoid conidia (Figure 1c). Cladosporium species produced olive-green to brown or black colonies (Figure 1d). Pestalotia sp. were characterized by white, cottony mycelia with black fusiform acervuli having two apical and one basal appendages (Figure 1a and Figure 1b).

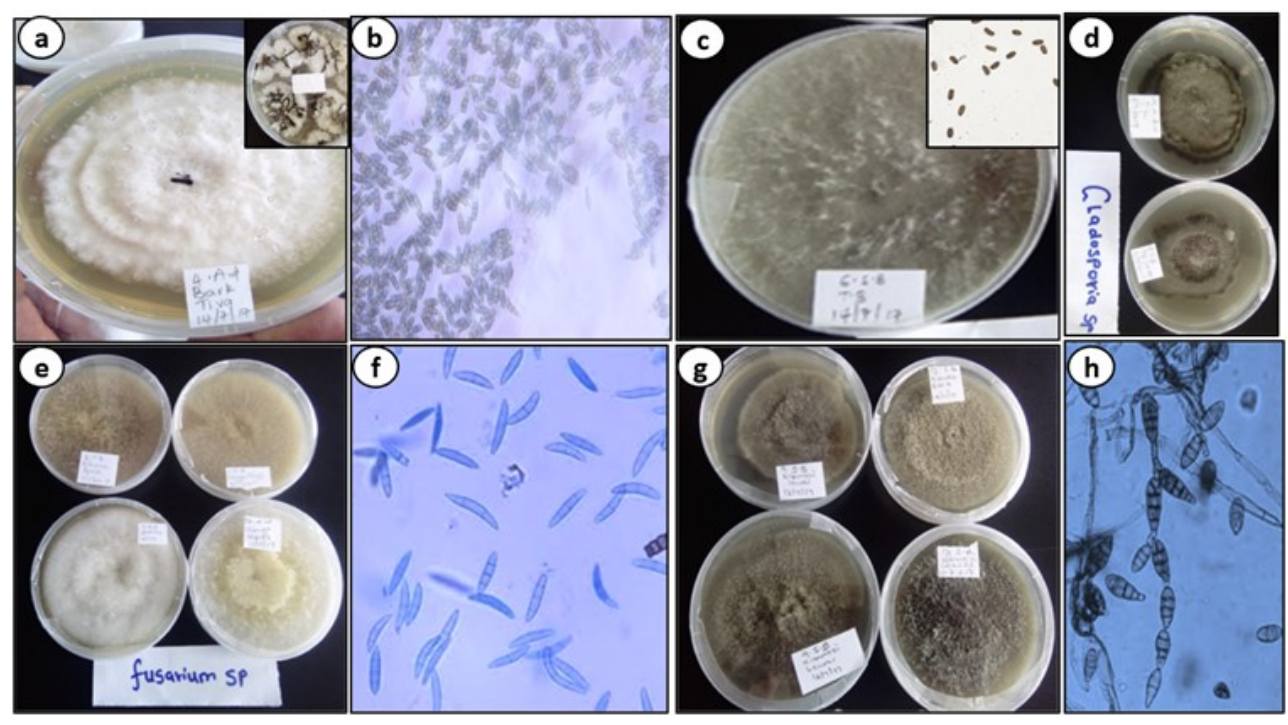

Figure 1. (a and b) cultures and spores of Pestalotia sp., (c) 5-day old culture of Botryosphaeria sp., and spores, (d) cultures of Cladosporium sp., (e and f) cultures and spores of Fusarium sp., (g and h) cultures and spores of Alternaria sp. 
Fusarium sp. was characterized by white to creamish and pink colonies with typically curved and 3-7 septate macroconidia (Figure 1e and Figure 1f). Alternaria spp. isolates produced dark grey to brown mycelia with long chained conidia (Figure 1g and Figure 1h).

\subsection{Fungal distribution in A. digitata and S. birrea trees in Eastern Kenya}

There was no significant difference $(\mathrm{p}<0.01)$ on fungal infestation between plant parts and across the sites, $(\mathrm{p}=0.259$ and $\mathrm{p}=0.756$, respectively). Analysis of fungi occurring in different plant parts showed that most of the fungi were isolated from diseased stem bark (50\%) followed by twigs and branches (35.2\%), leaves $(9.2 \%)$ and healthy plant parts $(5.6 \%)$ (Figure 3$)$.

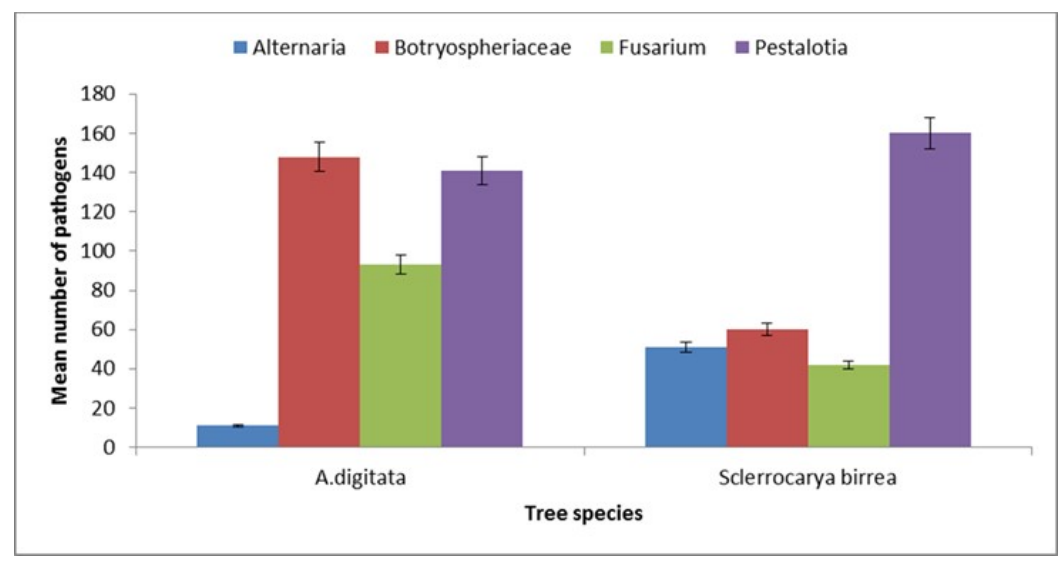

Figure 2. Frequency of fungi isolated from $A$. digitata and S. birrea trees in (Tiva, Ikanga and Mukange) Eastern Kenya and their distribution.

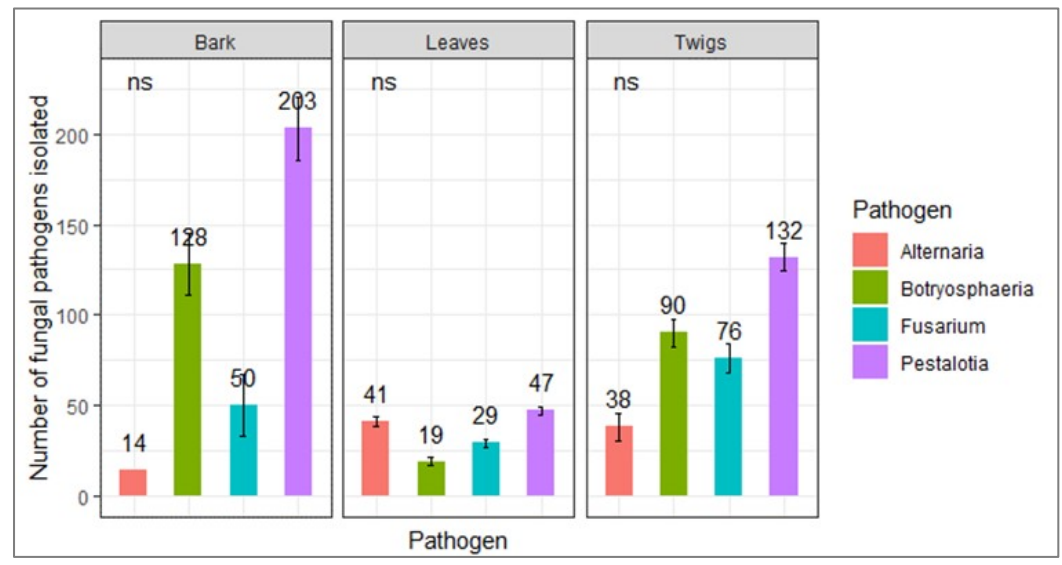

Figure 3. Fungi isolated from different plant parts of $A$. digitata and S. birrea trees.

Botryosphaeria and Pestalotia spp. were isolated more frequently on diseased tissues than healthy tissues. Botryosphaeria spp. occurred more often on A. digitata (71.4\%) than on S. birrea (28.6\%) while Pestalotia spp. occurred predominantly on S. birrea (53.3\%) than on A. digitata (46.7\%). Fusarium spp. occurred more on A. digitata $(69.2 \%)$ than on S. birrea $(30.8 \%)$, while Alternaria spp. Occurred more frequently on A. digitata (8.3\%) than S. birrea (16.7\%) (Figure 2). Pestalotia spp. occurred predominantly in Tiva than in Kibwezi and Ikanga, while Botryosphaeria spp. occurred more frequently in Kibwezi than any other regions (Figure 4). 


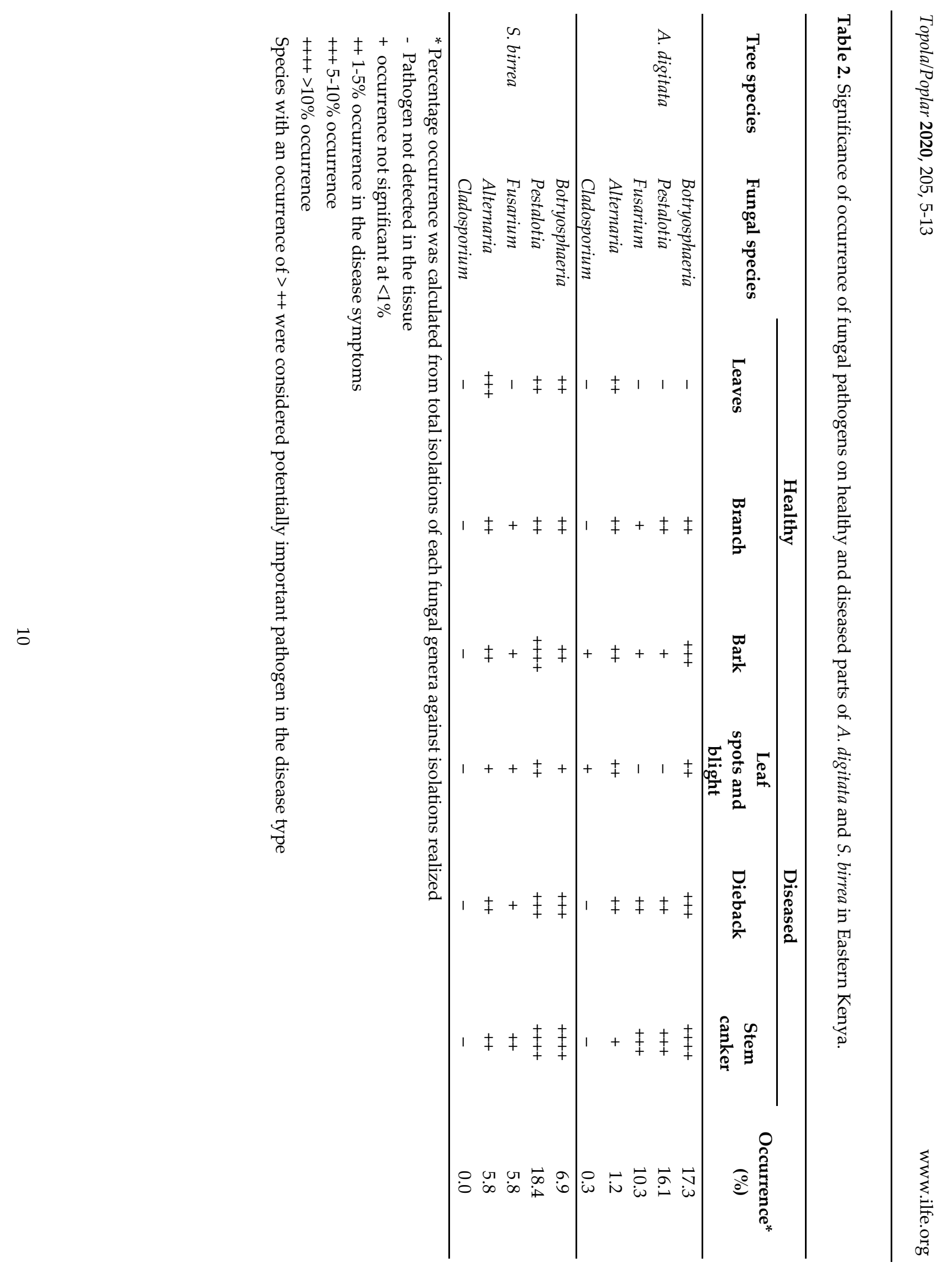




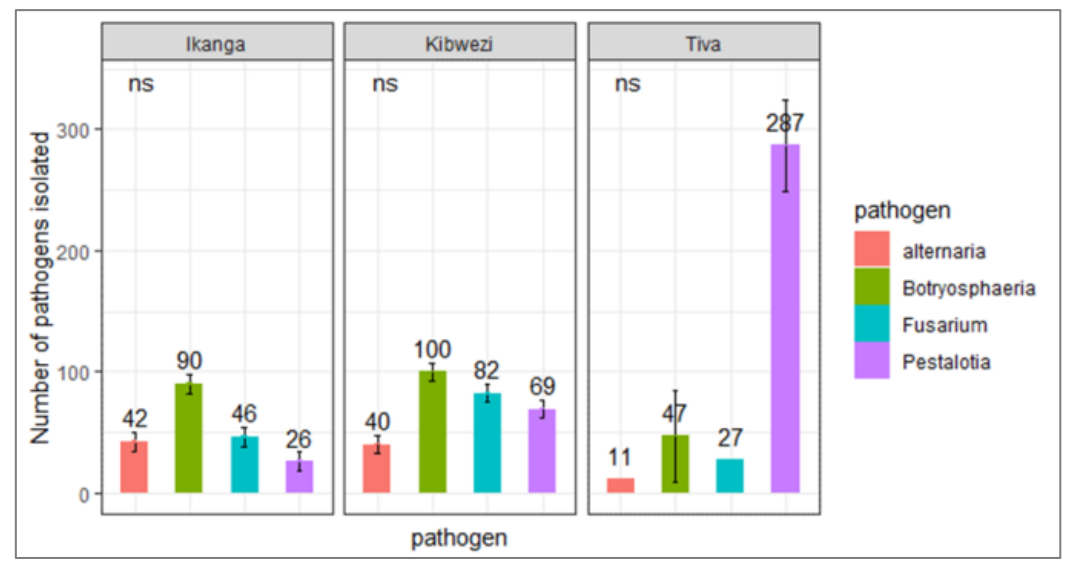

Figure 4. Fungal pathogens isolated from different sites.

\section{Discussion}

In this study disease incidence and severity was high during dry season than wet season, since high temperatures influence disease magnitude favouring disease development. The warm environmental conditions may have favoured proliferation of the disease impacting positively on the growth and survival of various pathogens resulting in increased incidence and severity. The observed high disease incidence and severity in S. birrea than A. digitata could be explain by marula planted closely compared to baobab possibly providing easier disease spread. since most S. birrea were planted on farms, pruning of trees seemed to aid disease spread within farms from infected plants to healthy plants through pruning tools. It also potrays marula to be highly susceptible to infections, therefore $A$. digitata could be better adaptive species for agroforestry systems in semi-arid areas than marula.

The fungal pathogens isolated co-occurred in the same sample which may increase the ability of the pathogens to overcome host's resistance especially under stressful conditions. The fungal isolates were also associated with both diseased and asymptomatic samples supporting previous observations that most fungi occur as latent pathogens but shifts to pathogenic phase due to unfavorable environmental conditions. In this study, prolonged drought periods could have predisposed marula and baobab trees in semi-arid areas to infection by fungal pathogens. Botryosphaeria and Pestalotia spp. were isolated most predominantly on diseased tissues than healthy samples and possibly play a role in the disease. Members of Botryosphaeria, Pestalotia, Fusarium and Alternaria are known to cause diseases on trees in Africa. Botryosphaeria causing canker and dieback disease was reported in Grevillea robusta in Kenya and on Melia volkensii as main hosts (Njuguna et al. 2011; Muthama et al. 2017).

The isolation frequency of Pestalotia spp. from marula could play a significant role in the canker and dieback disease although no record of isolations has been done on baobab. Members of Botryosphaeria species have been associated with canker and dieback diseases on many woody trees (Masberg et al. 2017). Recently, Botryosphaeria species were reported to cause canker disease on baobab and marula trees (Cherotich et al. 2019). Therefore, since Botryosphaeria species were isolated with the highest frequency from diseased tissues, it points to the possible that these fungi could be the cause of canker and dieback of baobab and marula trees in Kenya.

The emergence of such disease with a wide host range is a threat to agroforestry trees and will reduce the productivity of agroforestry systems. Further studies on ecology and implication of these pathogens is needed. 


\section{Conclusions and recommendations}

Adansonia digitata and Sclerocarya birrea trees were hosts of numerous fungal pathogens, including Botryosphaeria, Pestalotia, Fusarium, Cladosporium and Alternaria, some of which cause serious diseases of woody trees. These trees species could be a serious threat to agroforestry systems because they could act as a source or reservoir of fungal inoculums. The wide spread of canker and dieback disease observed on farms is a threat to domestication of these indigenous fruit trees and therefore there is a need for improvement of our understanding of host-pathogen dynamics and ecology of these pathogens in order to develop mitigation strategies.

\section{Acknowledgement}

Special thanks to World Agroforestry Centre for funding and supporting this research, as well as Kenya Forestry Research Center (KEFRI) for providing laboratory facilities. The authors also acknowledge pathology staff from KEFRI who assisted in field sampling and isolation.

\section{References}

1. Borrero, C., Castano, R., Avile, M. (2018): First report of Pestalotiopsis clavispora (Neopestalotiopsis clavispora) causing canker and twig dieback on blueberry bushes in Spain. Plant Disease 102: 1178.

2. Burgess, T.I., Tan, Y.P., Garnas, J., Edwards, J. (2019): Current status of the Botryosphaeriaceae in Australia. Australasian Plant Pathology 48: 35-44.

3. Chivandi, E., Mukonowenzou, N., Nyakudya, T., Erlwanger, K.H. (2015): Potential of indigenous fruit-bearing trees to curb malnutrition, improve household food security, income and community health in Sub-Saharan Africa: A review. Food Research International 76: 980-985.

4. Cherotich, S., Njuguna, J., Muchugi, A., Muthamia, J., Otaye, D., Graziosi, I., Kinyanjui, Z. (2019): Botryosphaeriaceae associated with baobab (A. digitata) and marula (S. birrea) in agroforestry system in Kenya. African Journal of Plant Science [In press].

5. Cruywagen, E.M., Slippers, B., Roux, J., Wingfield, M.J. (2017): Phylogenetic species recognition and hybridisation in Lasiodiplodia: a case study on species from baobabs. Fungal Biology 121: 420-436.

6. Gebauer, J., Adam, Y.O., Sanchez, A.C., Darr, D., Eltahir, M.E., Fadl, K.E., Hunsche, M. (2016): Africa's wooden elephant: the baobab tree (Adansonia digitata L.) in Sudan and Kenya: a review. Genetic Resources and Crop Evolution 63(3): 377-399.

7. Gebauer, J., El-Siddig, K., Ebert, G. (2014): Baobab (Adansonia digitata L.): a review on a multipurpose tree with promising future in the Sudan. European Journal of Horticultural Science 67: 155-160.

8. Jaetzold, R., Schmidt, H., Hornetz, B., Shisanya, C. (2010): Farm management handbook of Kenya, Vol. 2, Natural conditions and farm management information. PART II/B Central Kenya, Subparts B1 and B2 Central and Rift Valley Province Middle and Ministry of Agriculture, Kenya. Cooperation with the German Agency for Technical Cooperation (GTZ), Nairobi.

9. Jaetzold, R., Schmidt, H., Hornetz, B., Shisanya, C. (2012): Farm management handbook of Kenya Vol. 11. Natural conditions and farm management information: Atlas of Agroecological zones, soils and fertilizing by group district-subpart C1 Eastern province Kitui County. Ministry of agriculture, Nairobi.

10. Jamnadass, R.H., Dawson, I.K., Franzel, S., Leakey, R.R.B., Mithofer, D. F. K., Akinnifesi, F. K. and Tchoundjeu, Z. (2011): Improving livelihoods and nutrition in Sub-Saharan 
Africa through the promotion of indigenous and exotic fruit production in small holders' agroforestry systems. International Forestry Review 13(3): 338-354.

11. Kumad, J.R.S., Jarial, P.D., Thakur, S.K., Banyal, M.R.K. (2017): Pestalotia versicolor a Predominant pathogen associated with decline disease of mango in sub-tropical zone of Himachal Pradesh. International Journal of Bio-resource and Stress Management 8(1): 122-128.

12. Kehlenbeck, K., Asaah, E., Jamnadass, R. (2013): Diversity of indigenous fruit trees and their contribution to nutrition and livelihoods in sub-Saharan Africa: examples from Kenya and Cameroon. In: Fanzo, J., Hunter, D., Borelli, T., Mattei, F. (eds). Diversifying food and diets: using agricultural biodiversity to improve nutrition and health issues in agricultural biodiversity. London, Earthscan. pp. 257-269.

13. Marsberg, A., Kemler, M., Jami, F., Nagel, J.H., Postma-Smidt, A., Naido, S., Wingfield, M.J., Crous, P.W., Spatafora, J., Hesse, C.N. (2017): Botryosphaeria dothidea: a latent pathogen of global importance to woody plant health. Molecular Plant Pathology 18: 477-488.

14. Mehl, J.W., Slippers, B., Roux, J., Wingfield, M.J. (2017): Overlap of latent pathogens in the Botryosphaeriaceae on a native and agricultural host. Fungal Biology, 121: 405-149.

15. Mkwezalamba, I., Munthali, C.R. Missanjo, E. (2015): Phenotypic Variation in Fruit Morphology among Provenances of Sclerocarya birrea (A. Rich.) Hochst. International Journal of Forestry Research, 2015:8.

16. Muthama, A.M., Njuguna, J.W., Francis, K. (2017): Botryosphaeriaceae fungal species as potential pathogens of Meliaceae in arid and semi-arid lands of Kenya. The Indian Forester 143: 890-893.

17. Njuguna, J.W., Barklund, P., Ihrmark, K., Stenlid, J. (2011): A canker and dieback disease are threatening the cultivation of Grevillia robusta on small-scale farms in Kenya. African Journal of Agricultural Research 6(3): 748-756.

18. Nhung, N.P., Thu, P.Q., Dell, B., Chi, N.M. (2018): First report of canker disease in Dalbergia tonkinensis caused by Fusarium lateritium and F. decemcellulare. Australasian Plant Pathology 47: 317-323.

19. Pavlic-Zupanc, D., Maleme, H.M., Piškur, B., Wingfield, B.D, Wingfield, M.J., Slippers, B. (2017): Diversity, phylogeny and pathogenicity of Botryosphaeriaceae on non-native Eucalyptus grown in an urban environment: a case study. Urban Forestry and Urban Greening 26(1): 139-148.

20. Rayner, R.W. (1970). A mycological color chart. Kew, Surrey, UK: CMI and British Mycological Society. p. 34.

21. Sinniah, G.D., Munasinghe, C.E., Mahadevan, N., Jayasinghe, S.K., Kulatunga, D.C.M. (2017): Recent incidence of collar canker and dieback of tea (Camellia sinensis) caused by Fusarium solani species complex in Sri Lanka. Australasian Plant Disease Notes 12: 41.

22. Stadlmayr, B., Charrondière, U.R., Eisenwagen, S., Jamnadass, R., Kehlenbeck, K. (2013): Nutrient composition of selected indigenous fruits from sub-Saharan Africa. Journal of Science in Food Agriculture 93: 2627-2636.

23. Zhao, H.H., Yue, Q.H., Liang, C. (2014): The pathogen causing Pestalotiopsis twig dieback of blueberry. Mycosystema 33(3): 577-583. 